\title{
Eutrophication in aquatic ecosystems: a scientometric study
}

\author{
Eutrofização em ecossistemas aquáticos: um estudo cienciométrico
}

Jéssica Alves da Costa ${ }^{1}$, João Paulo de Souza ${ }^{2}$, Ana Paula Teixeira ${ }^{2}$, João Carlos Nabout ${ }^{2}$ and Fernanda Melo Carneiro ${ }^{3}$

${ }^{1}$ Universidade Estadual de Goiás - UEG, Bairro Jardim Novo Horizonte 2, CEP 76200-000, Iporá, GO, Brasil

${ }^{2}$ Universidade Estadual de Goiás - UEG, Campus de Ciências Exatas e Tecnológicas - CCET, BR-153, no 3105, CEP 75132-903, Anápolis, GO, Brasil

${ }^{3}$ Universidade Estadual de Goiás - UEG, Av. Prof. Alfredo de Castro, s/n, Bairro Chácara do Governador, CEP 74870-038, Goiânia, GO, Brasil

*e-mail: fernanda.carneiro@ueg.br

Cite as: Costa, J.A. et al. Eutrophication in aquatic ecosystems: a scientometric study. Acta Limnologica Brasiliensia, 2018, vol. 30, e2.

Abstract: Aim: Reveal the direction for future studies about eutrophication, or even reveal the preoccupation among the scientific community about this environmental problem. With a systematic synthesis of eutrophication studies, scientists may be able to understand the state of the literature on aquatic ecosystems around the world. This study intends to identify the main factors used to control algal blooms and the eutrophication process, the countries and environments which have more research about this theme or even identify the articles' subjects in different periods (e.g.: Experimental, theoretic, monitoring, conservation). Methods: We analyzed all studies published in the Thomson ISI Web of Science on both eutrophication and phytoplankton between 2001 and 2016. Results: During the period analyzed, we observed an increase in concern about this subject. Authors from institutions in the USA and China wrote most of the studies. The most important geographic and socioeconomic aspects to determine the publication number were total area and HDI respectively. However, the main determinant for the publication about this subject was international collaboration. Some of the most actual themes in ecology and conservation (e.g.: functional groups, climate change, experiment, perdition models, regional scales, invasive species) were addressed in the studies analysed. Invasive species such as Tilapia and Cylindrospermopsis raciborskii were the most cited species on these keywords. Conclusion: Despite the current issues addressed in the studies on phytoplankton and eutrophication, some subjects, such as climate change or spatial pattern, were only common in years more recent. Even though studies focusing in functional diversity are highly relevant for conservation, they were not common in any year studied. The major determinant factor related to the increasing in eutrophication knowledge was the international collaboration

Keywords: Cyanobacteria; collaboration; climate-change; hydrology; invasive species.

Resumo: Objetivos: Revelar a direção de futuros estudos ou mesmo a preocupação da comunidade científica sobre esse problema ambiental. Com uma revisão sistemática dos estudos sobre eutrofização cientistas podem ser capazes de entender o estado da literatura sobre ecossistemas aquáticos no mundo. Nesse trabalho pretende se identificar os principais fatores usados para controlar floraçóes e processos de eutrofização, os países e ambientes com mais pesquisar sobre o tema e ainda os principais temas abordados em diferentes períodos. Métodos: Nós analisamos todos os estudos publicados na base de dados Thomson ISI Web of Science sobre eutrofização e fitoplâncton 
entre 2001 e 2016. Resultados: Durante o período analisado observamos um aumento no número de publicaçóes. Autores dos EUA e da China escrevam a maior parte dos estudos. Os aspectos socioeconômicos e geográficos mais importantes para determinar o número de publicaçóes foram área total do país e IDH. Entretanto, o principal determinante para publicação nessa área foi o número de colaboraçóes internacionais. Alguns dos temas mais atuais em ecologia e conservação (ex.: grupo funcional, mudanças climáticas, modelos de predição, escalas regionais, espécies invasoras) foram abordados nos estudos analisados. Espécies invasoras como Tilápia e Cylindrospermopsis raciborskii foram as espécies mais citadas nas palavras chaves. Conclusáo: Apesar das abordagens atuais nos estudos de eutrofizaçáo e fitoplâncton, alguns temas foram comuns apenas nos recentes anos como mudanças climáticas e padróes espaciais. Apesar da relevância da diversidade funcional nos estudos de conservaçáo, essa palavra não foi comum em nenhum dos anos estudados. $\mathrm{O}$ fator determinante para aumento do conhecimento sobre eutrofização foram as colaboraçóes internacionais.

Palavras-chave: cianobactéria; colaboração; mudanças-climática; hidrologia; espécie invasora.

\section{Introduction}

Eutrophication is an environmental problem caused by the increment of nutrients, such as nitrogen and phosphorus, in aquatic ecosystems. These nutrients have a considerable variety of sources; they may not only come from urban and industrial sewage but also from agricultural lands (Johnson et al., 2007; Donald et al., 2011). Therefore, land use information is important for identifying the trophic status in aquatic ecosystems (Downing et al., 1999).

Nutrient loading causes a rapid elevation in the primary production of phytoplankton (Drupp et al., 2011), resulting in extensive changes in physical, chemical, and biological characteristics (Carneiro et al., 2014). Some algal species that produce toxins are favored when there is more organic matter than can be consumed or decomposed (Carpenter, 2005). Phytoplankton is a group of organisms that is sensitive to nutrient variation; for this reason, it is an important indicator group of eutrophication (Cottingham et al., 1998). Biodiversity losses, water pollution, increases in the emission of greenhouse gases, and an elevation in the costs of water treatment are some of the environmental and economic consequences of eutrophication (Tilman et al., 2001).

Several scientific studies have reported eutrophication as a growing preoccupation for the scientific community around the world (Vörösmarty et al., 2010). Therefore, a systematic review of this subject may identify some key variables to monitor this complex process (e.g. land-use) or even lead to future research (e.g.: climate-change). An effective way to produce a systematic review on this subject is through a scientometric study, which allows a quantitative understanding of research trends (e.g. Carneiro et al., 2008; Alves et al., 2014; Nabout et al., 2015). With a systematic synthesis of eutrophication studies, scientists may be able to understand the state of the literature on aquatic ecosystems around the world, and identify the main factor, which control algal blooms and the eutrophication process.

A scientometric study of eutrophication may also reveal the representability of this subject in the scientific literature. Thus, for this study we used a scientometric approach to investigate the scientific literature on eutrophication in aquatic ecosystems. To know if the interest of the scientific community is increasing and changed over the time. We posed the following questions: (1) Did the number of studies increase over time? (2) In studying eutrophication processes, have there been any change in the tolls or variables? (3) What are the countries that have made major contributions during this period? (4) What environment has the largest number of works on eutrophication? (5) What types of environmental drivers and taxonomic groups are most frequently studied? (6) What are the main characteristics that influence the number of publications? (7) What are the most collaborative countries in this field and how is the Network of international collaboration among them?

\section{Material and Methods}

We selected all articles in the Thomson ISI Web of Science database published from 2001 to 2016, with the words "eutrophic*" and "phytoplankton*" present in the keywords, abstract, or title. From each article, we retained the following information: year of publication, name and mailing address of the first author, address of the institution of the authors, and keywords. To study the temporal trends of the publication during the period of interest, we plotted the number of published papers over the years and examined the trend through a linear regression model. To identify the countries with the greatest number of publications we used the location of the institution of the corresponding author. Using the keywords, we recorded the most frequently studied environments, and taxonomic groups. The keywords are important elements 
used to represent the contents of the articles (Carneiro et al., 2008).

The remaining keywords were analyzed using a Correspondence Analysis (CA) with the vegan package for the R program version 3.1.1 (Oksanen et al., 2013). The CA was used to identify the similarity between the years (2001-2016) in relation to the keywords used in the articles, since it is possible to know which keyword are most common in each year (sampling unit) and how these years are similar (Legendre \& Legendre, 1998). To identify if the keywords had a significant relationship with the years in the CA we used a chi-square test using the $\mathrm{R}$ program. Other scientometrics studies have also used ordination analysis to investigate the temporal trends of keywords (see Carneiro et al., 2008; Nabout et al., 2012).

Using the authors' addresses it was possible to built an international collaborative network through a Social Network Analysis (SNA). This analysis base itself on the investigation of the relationship among entities, in this study the countries, and on patterns and implications of these relationship (Csardi \& Nepusz, 2006). The network can be built using the frequency of interactions that each country has with others. Thus, higher the frequency of interactions between two countries closer to each other in the network they will be. Furthermore, the most interactive country will be centred in the network.

To evaluate if geographical and socioeconomic characteristics influence the number of articles published per country, we sampled geographical data (i.e. Total area, coastal extension, inland area occupied by aquatic ecosystems, Gross Domestic Product (GDP)) and socioeconomic information (life expectancy, development status $(\mathrm{DC}=$ developed country, $\mathrm{DIC}=$ developing countries, $\mathrm{LDC}=$ less developed country, LLDC= least developed country), human development index (HDI), school life expectancy) for each country (CIA, 2017). Using these variables, we built a multiple regression model and we relied on the Akaike Information Criterion to select the best model. This statistic rewards prediction precision while penalizing model complexity (Burnham \& Anderson, 2004). We also verified whether the number of international collaborations have an influence on the number of papers published per country.

\section{Results}

During 2001 to 2016, 4,949 papers were published with the words "eutrophication" and "phytoplankton" in their keywords, abstract, or title. The number of papers on this subject increased during the period analyzed (Figure 1).

The CA indicated a temporal trend during the years analyzed. The main gradient of the subjects was in according to the Axis 1 that explain $16.01 \%$ in the keywords variation during the years (Figure 2). There are few keywords associated to the years 2001 to 2006. During the years 2007 to 2015, there are more themes, but in general, these subjects were not specific for one year (keywords). In 2016 the most common keywords were trophic change, spatial and temporal pattern and invasive species (Figure 2)

The proximity of each year in Figure 2 indicates the similarity in the subject matters (keywords). For instance, in 2001 the most common keyword was "culture". In 2002, it was "Functional groups". From 2003 to 2005 the keywords "Trophic gradient", "Acid environments", "population". Followed by "Bioassay", "HPLC" and "Pigments". "Global change", "Risk assessment" and "Bioaccumulation," which were common during 2008, 2009, 2012, 2014 and 2015. In 2009, "Monitoring" and "Bioindicator" were common. Keywords which indicate studies in regional scales (e.g.: watershed and hydrodynamic) were common from 2008 (Figure 2).

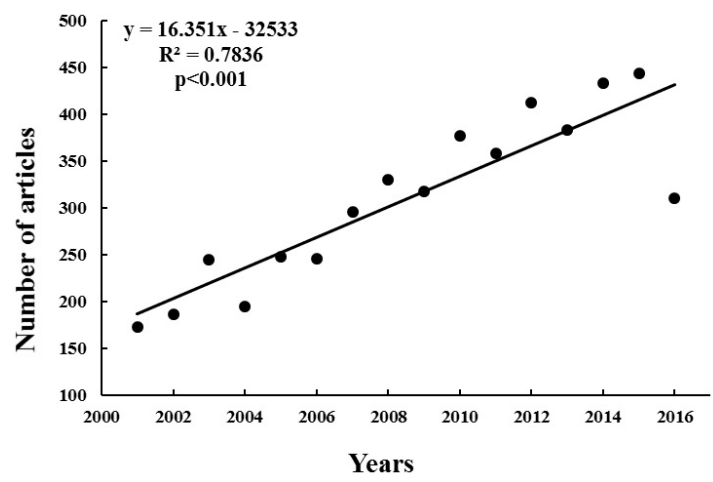

Figure 1. Number of papers published during 2001-2016 in the ISI database.

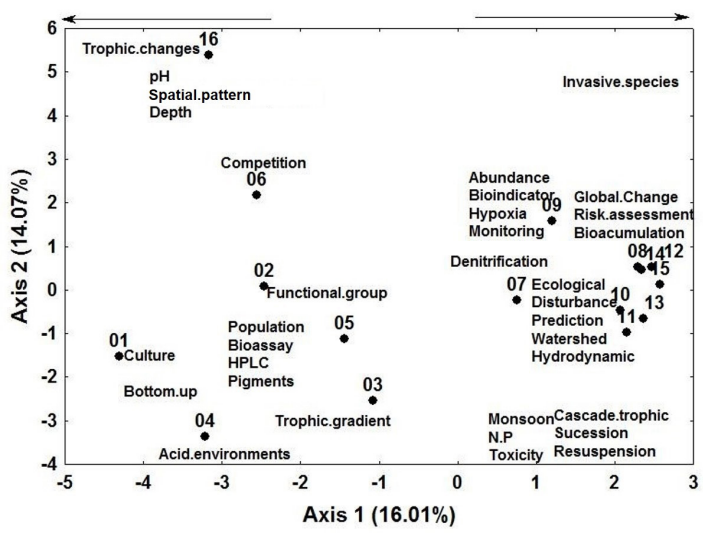

Figure 2. Correspondence Analysis (CA) showing the keywords most associated to the years studied (from 2001 to 2016). The first two axes explained $30.08 \%$ of the variation in keywords during the years analyzed. 
In the years surveyed, a total of 108 countries have either published or collaborated in papers about eutrophication, most of these studies were from institutions in the USA, followed by those in China, Germany and England (Figure 3). When we analyzed the papers' keywords, the countries that appeared the most were China (cited 27 times), Brazil (cited 26 times), and USA (cited 11 times).

From the total of encountered articles, a large fraction, 3,839 (77,6\% of the articles), was published without international collaboration. The countries present in Figure 4 collaborated in at least 20 articles published about phytoplankton and eutrophication from 2001 to 2016; together these countries account for $89 \%$ of the papers with international collaboration. The nearest countries in Figure 4 had strong collaboration, for instance, France, USA, Germany and Netherlands. Other examples are Norway and Finland, Russia and Belgium. The most peripheric countries (Figure 4, Tunisia, Turkey, Greece, South Korea and Mexico) had a lower number of collaborations when compared to the most centralized countries (Figure 4).

The number of collaboration explain alone $92 \%$ of the number of articles published. Each new international collaboration increased 0.75 times the publication number (Figure 5).
When socioeconomic and geographical variables were considered in a multiple regression using Akaike criterium, only human development and total area of the country were important to explain part of the publication number $\left(r^{2}{ }_{\text {adj }}=0.3003 ; p=0,000008\right)$. In general, the countries with high HDI and largest area had the most number of publication. However, in the less developed countries (LDC) the total area had a negative effect in the publication number (Figure 6).

The majority of the articles were developed in freshwater ecosystems, among those Lake was the most frequent one, followed by River and Reservoir (7a). Among the taxonomic groups, the most commonly cited in the keywords were Cyanophyceae followed by Zooplankton, Macrophytes, Bacillariophyceae and Fish (Figure 7b).

Several Cyanophyceae appear among the most cited organisms in the keywords, but the two most common were Microcystis sp. and Cylindrospermopsis raciborskii (Woloszynska) Seenayya \& Subba Raju. Some macroalgae such as Phaeocystis sp. and Ulva sp. were also common. Invasive species such as Zebra mussel and Tilapia had high citation in the articles about phytoplankton and eutrophication (Figure 8).

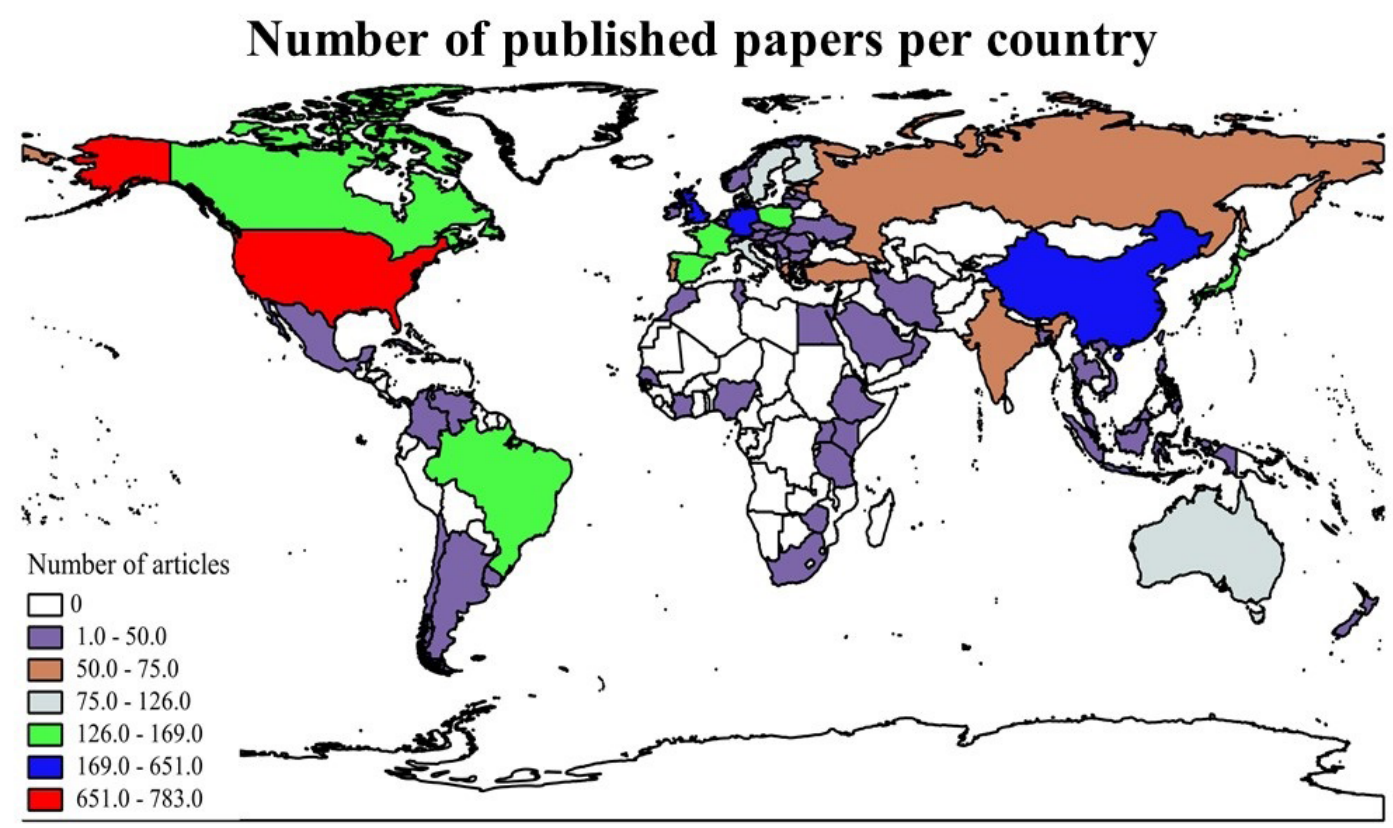

Figure 3. The most common institution of the correspondence author of the papers analyzed during 2001-2016. 


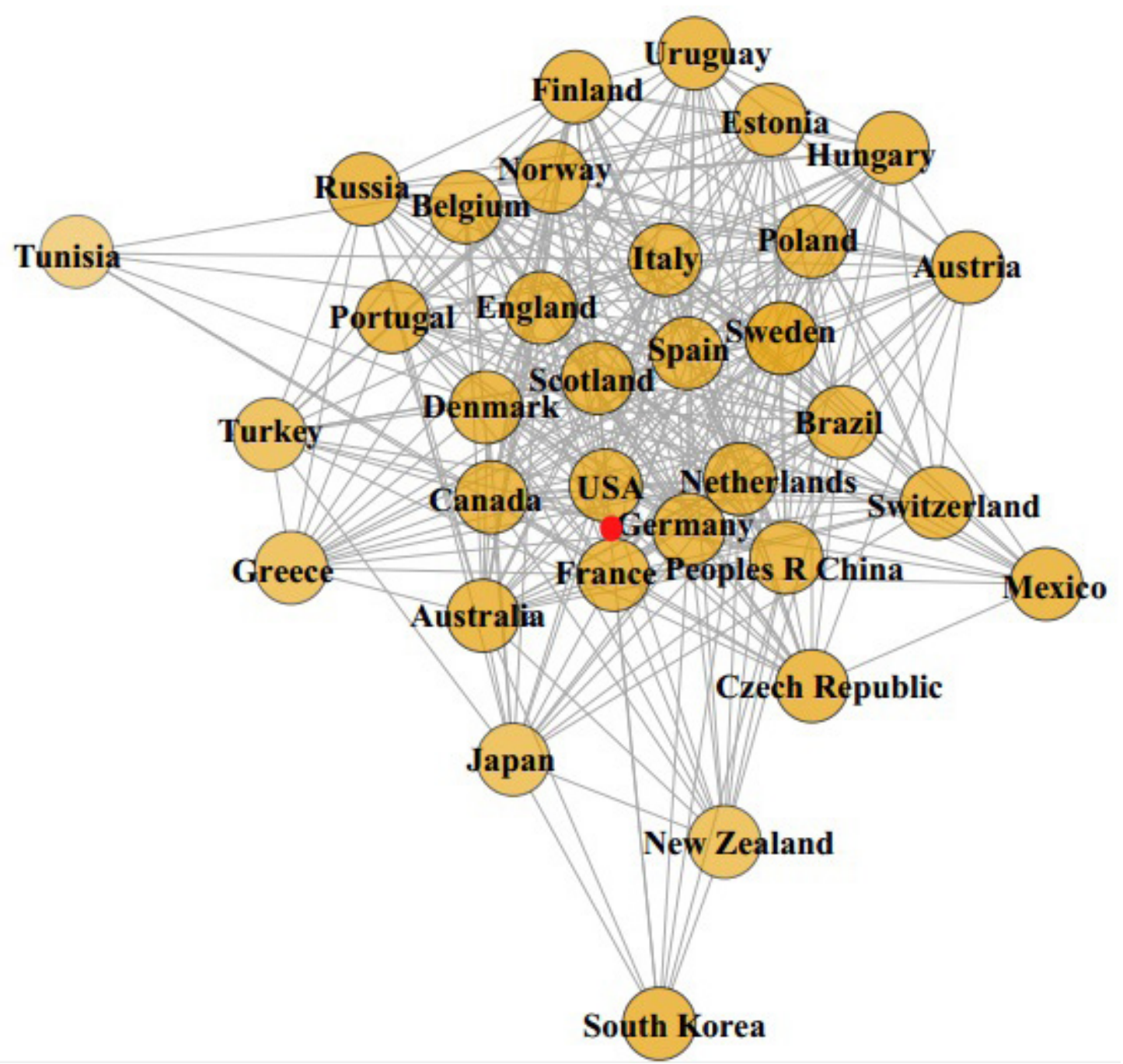

Figure 4. Collaboration among countries that collaborated in at least 20 papers. The most centralized countries had the most number of collaboration, the center of the network is represented by a red dot.

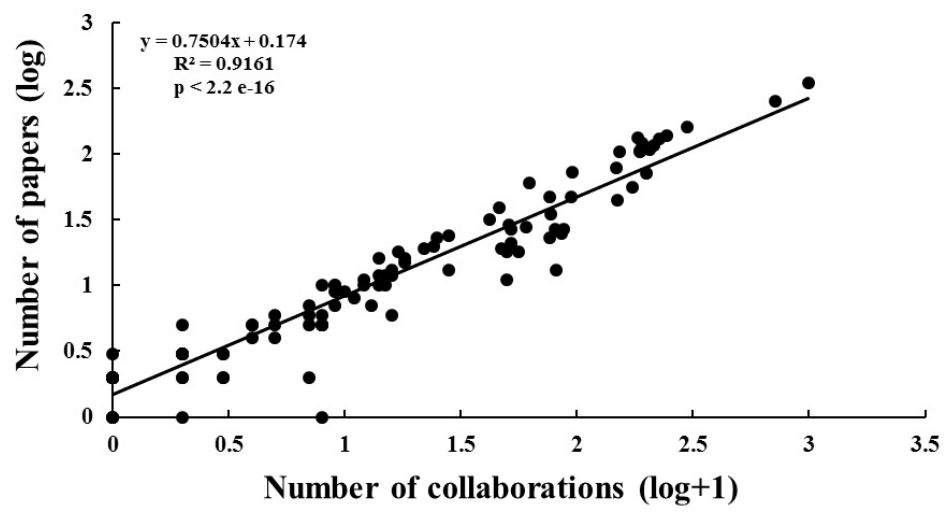

Figure 5. Number of papers published in function of the number of collaboration. Regression model between collaboration number and papers number. 


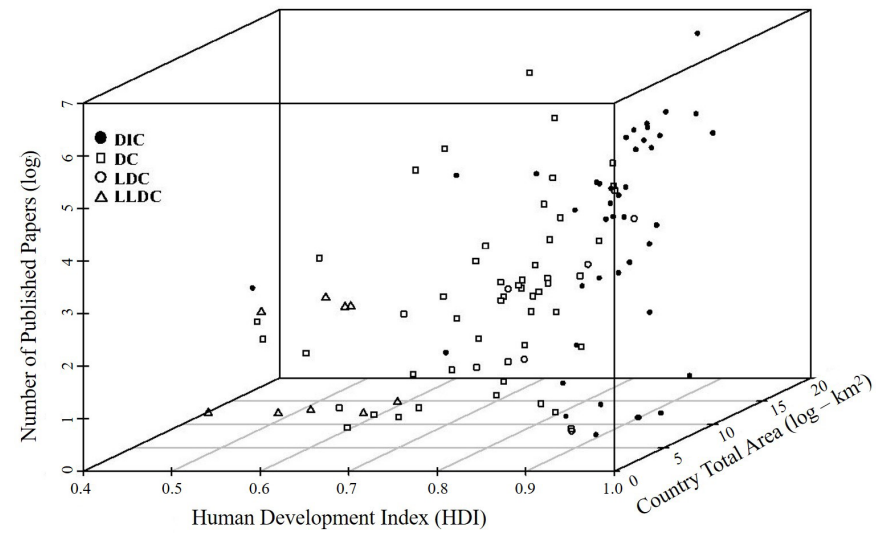

Figure 6. Multiple regression of the publication number using HDI and total area as predictors. $\mathrm{r}^{2}{ }_{\text {adj }}=0.3003$; $p=0,000008$. The countries are separate by the economic status $\mathrm{DC}=$ developed country, DIC $=$ developing countries, LDC= less developed country, LLDC= least developed country.

(a)

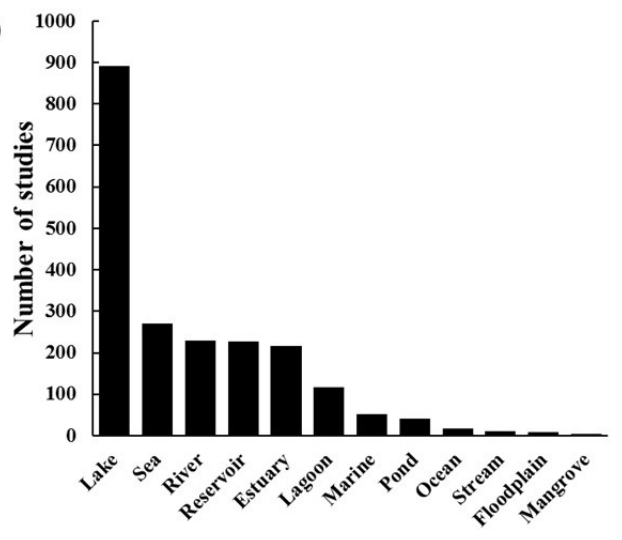

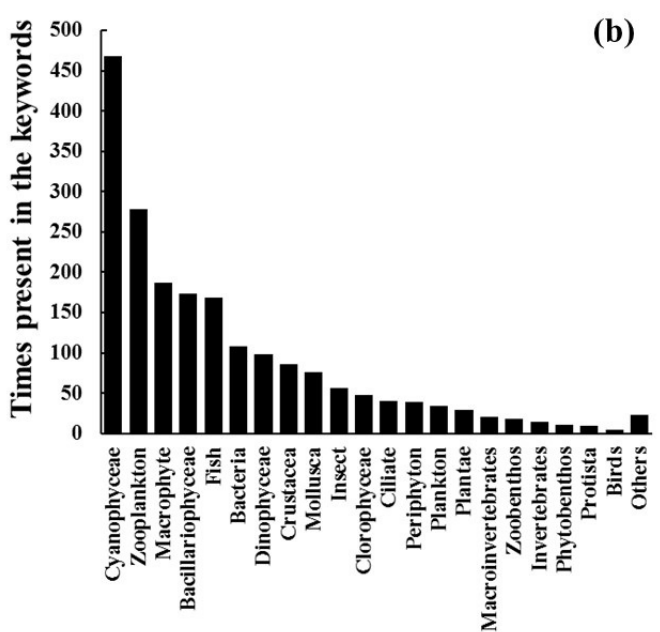

Figure 7. (a) Environments that appeared most often in the keywords. (b) Taxonomic groups that appeared most often in the keywords of the articles on phytoplankton and eutrophication published between 2001 and 2016.

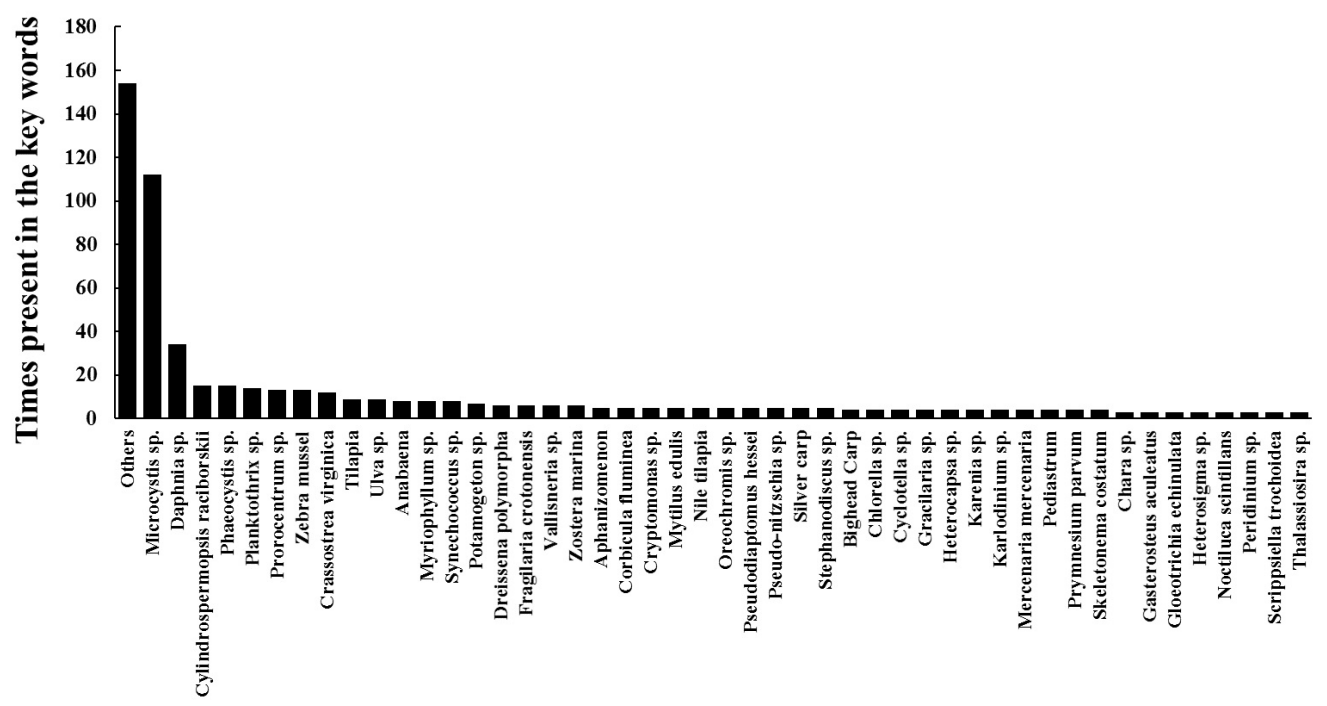

Figure 8. Organisms that appeared most often in the keywords of the articles on phytoplankton and eutrophication published between 2001 and 2016. 


\section{Discussion}

Temporal trends are important ways to assess the quantitative growth of an area of research. This study has highlighted the increasing number of papers on eutrophication from 2001 to 2016. Previous scientometric studies have also reported a high number of studies on eutrophication (Carneiro et al., 2008; Alves et al., 2014; Nabout et al., 2015). It is possible that the decrease in the number of publications during some years was a reflex from the world economic crises, others scientometric studies have also observed a decrease in the number of publications in the years following economic crises (see Triunfol, 2007; Miguel et al., 2010).

In addition, increased urbanization has directed the scientific community to solve problems related to eutrophication. In the keywords of eutrophication studies, there are many papers on China, a developed country with high rates of urbanization. Urbanization and its consequences (e.g. increased human population) have led to an increase in eutrophication events (e.g. Fontana et al., 2014). In fact, the most important geographical and socioeconomic factor to determine the publication number about eutrophication and phytoplankton were the HDI and total area. Therefore, the highest number of papers were on biggest and rich countries such as China and the USA. The USA is a developed/industrialized country; it is responsible for a substantial part of publications when compared to developing countries (Meneghini et al., 2006). For instance, the USA has invested more than $\$ 20$ million to mitigate the impact of eutrophication in aquatic ecosystems, mainly in areas with a potential for tourism (Lapointe \& Bedford, 2007).

Only $22.4 \%$ of the papers about eutrophication and phytoplankton feature international collaboration. However, this factor alone explains more than $90 \%$ of the number of publications. For studies about eutrophication the increase in collaborative papers are associated with: i) environmental issues (such as eutrophication) are complex and require the collaboration of researchers from different fields of science. The collaboration generates articles with better quality and greater impact (Finlay et al., 2012; Leimu \& Koricheva, 2005; Adams et al., 2005). ii) Some studies of eutrophication are costly, especially related to genetic and molecular aspects, therefore, collaborative work permit sharing the costs. iii) Several countries have directed resources for studies in aquatic environments, and several times these resources come from agreements with several countries.
In Natural Sciences, it is expected that an increase of 2.3 times the number of citation each time will double the number of coauthored papers (Ronda-Pupo \& Katz, 2016). International co-authorship is highest between 10 to 25 years of career. In general, it is lowest among woman more than men (Iglič et al., 2017). About the eutrophication studies, factors such as language and location appear to increase the international collaboration number. Between the countries with high collaboration only the USA and China are not European countries.

Studies of eutrophication have been shown to be dynamic over time, and keywords can demonstrate these changes (e.g. Carneiro et al., 2008; Nabout et al., 2012). The keywords in the most recent eutrophication studies indicate a better characterization of the environment with more complete studies which include Watershed, hydrodynamic and Climate change (from 2008 to 2015). Climate change is often associated with the overloading of nutrients, consequently causing eutrophication and promoting changes in plankton community composition (Posch et al., 2012; Suikkanen et al., 2013; see Anderson et al., 2002). A good understanding of hydrodynamic is essential to understanding anthropogenic effects on aquatic ecosystems (i.e. agriculture and climatic change; Hakanson, 2008; Carpenter et al., 2015). Studies on eutrophication have been more often with temporal gradient (Time-series) than spatial, only in 2016 was spatial scale also considered. In 2002, the most common keyword was "functional group", the phytoplankton functional groups were created by a publication in 2002 which has more than 600 times cited (Reynolds et al., 2002).

In this study, the most common environments studied were lakes followed by sea, while in another scientometric study only about phytoplankton the most common environments were the sea (Carneiro et al., 2008). Lakes, globally, represent $68 \%$ of the surface of inland waters and the main impacts reported in the lakes are eutrophication and invasive species (Beeton, 2002). For example, the Taihu Lake, the third largest lake in China in the last few decades, the population and industry have increased significantly in the surrounding region (Liu et al., 2010; Qin et al., 2010). Local inhabitants of the lakes have reported a strong and unpleasant odor in the lakes due to the dense cyanobacteria population (Qin et al., 2010). Similarly, nutrient levels increased dramatically in the Adriatic Sea during the late $20^{\text {th }}$ century 
(Sangiorgi \& Donders, 2004) and eutrophication is an ongoing problem in the Baltic Sea, where clean water is increasingly turbid due to algal proliferation (Jesper \& Laamanen, 2009).

Many taxonomic groups have been investigated with respect to eutrophication, and in this study we found a predominance of cyanobacteria. Cyanobacteria have biological advantages in environments with low oxygen concentrations, high $\mathrm{pH}$ values, and high nutrient concentrations (Azevedo, 1998). In these conditions, this group is likely to develop blooms and release toxic substances (Soares et al., 2007; Oliveira et al., 2010; Paerl et al., 2011). About the species more often in the studies, Mycrocystis and Planktothrix are the main genus responsible to produce the microcystins in bloom algal (Bukowska et al., 2017). There are several studies that associated the presence of invasive species Cylindrospermopsis raciborskii to global warming (Kokocinski et al., 2017). Tilapia also have been reported as an invasive species and associated with eutrophication events. By supplying considerable amount of nutrients, it promotes an increase of algae blooms (Figueredo \& Giani, 2005). Daphnia, also common in this study, is an organism widely used in ecotoxicological testing, even cyanotoxin test (Bownik, 2017).

Macrophytes are also likely to be favoured in elevated nutrient concentrations, causing changes in the biological community in aquatic ecosystems (Thomaz et al., 2003; Bini et al., 2010). The considerable growth of Dinophyceae populations is also indicative of eutrophication. This group is responsible for a known phenomenon called red tide (Saetre et al., 1997). Bacillariophyceae is an efficient indicator of water quality (Vilmi et al., 2015), diatom species blooms can occur in eutrophic environments. In addition, the Zooplankton and Bivalvia, also common in the keywords, are important predators of phytoplankton communities and for this reason are affected by the eutrophication process (Cahoon \& Owen 1996; Jones \& Jeppesen, 2007).

Some of the actual subjects of the ecological studies such as global change, regional aspects (e.g.: Watershed), invasive species and functional groups were observed in the eutrophication studies. Experimental and technological approaches were already present in older studies analysed. However, the spatial approach was recent in the studies (e.g.: 2016). Even though studies focusing in functional diversity are highly relevant for conservation, they were not common in any year studied. Keywords associated to the restauration of these environments were not often. Aspects like the number of freshwater environments or coastal extension appear do not influence the number of studies about the theme; for instance, the total area and the HDI explain a part of these publication. The stronger factor to determine the number of publication was the number of international collaboration. In general, countries with physical proximity and similar language frequently collaborated more among them. The increase in number of international collaborations can highlight this subject, and consequently the interest by the aquatic ecosystems conservation.

\section{Acknowledgements}

João Paulo de Souza and Ana Paula Teixeira give thanks to UEG and CAPES scholarship respectively. João Carlos Nabout is supported by a CNPq productivity fellowship. Fernanda Melo Carneiro is supported by a UEG productivity fellowship (PROBIP- UEG). We are also grateful to Robert Crowe for English revision.

\section{References}

ADAMS, J.D., BLACK, G.C., CLEMMONS, J.R. and STEPHAN, P.E. Scientific teams and institutional collaborations: evidence from U.S. universities 19811999. Research Policy, 2005, 34(3), 259-285. http:// dx.doi.org/10.1016/j.respol.2005.01.014.

ALVES, M.T.R., TERESA, F.B. and NABOUT, J.C. A global scientific literature of research on water quality indices: trends, biases and future directions. Acta Limnologica Brasiliensia, 2014 26(3), 245-253. http://dx.doi.org/10.1590/S2179$975 \times 2014000300004$

ANDERSON, D.M., GLIBERT, P.M. and BURKHOLDER, J.M. Harmful algal blooms and eutrophication: nutrient sources, composition, and consequences. Estuaries, 2002, 25(4b), 704-726. http://dx.doi.org/10.1007/BF02804901.

AZEVEDO, S.M.F.O. Toxinas de cianobactérias: causas e consequências para a saúde pública. Med Online (Bergheim), 1998, 1(3), 12-16.

BEETON, A.M. Large freshwater lakes: present state, trends, and future. Environmental Conservation, 2002, 29(01), 21-38. http://dx.doi.org/10.1017/ S0376892902000036.

BINI, L.M., THOMAZ, S.M. and CARVALHO, P. Limnological effects of Egeria najas Planchon (Hydrocharitaceae) in the arms of Itaipu Reservoir (Brazil, Paraguay). Limnology, 2010, 11(1), 39-47. http://dx.doi.org/10.1007/s10201-009-0286-4.

BOWNIK, A. Daphnia swimming behaviour as a biomarker in toxicity assessment: a review. The Science 
of the Total Environment, 2017, 601-602, 194-205. http://dx.doi.org/10.1016/j.scitotenv.2017.05.199. PMid:28551538.

BUKOWSKA, A., KALIŃSKI, T., KOPER, M., KOSTRZEWSKA-SZLAKOWSKA, I., KWIATOWSKI, J., MAZUR-MARZEC, H. and JASSER, I. Predicting blooms of toxic cyanobacteria in eutrophic lakes with diverse cyanobacterial communities. Scientific Reports, 2017, 7(1), 8342. http://dx.doi.org/10.1038/s41598-017-08701-8. PMid:28827675.

BURNHAM, K.P. and ANDERSON, D.R. Multimodel inference: understanding AIC and BIC in Model Selection. Sociological Methods \& Research, 2004, 33(2), 261-304. http://dx.doi. org/10.1177/0049124104268644.

CAHOON, L.B. and OWEN, D.A. Can suspension feeding by bivalves regulate phytoplankton biomass in Lake Waccamaw, North Carolina? Hydrobiologia, 1996, 325(3), 193-200. http://dx.doi.org/10.1007/ BF00014984.

CARNEIRO, F.M., NABOUT, J.C. and BINI, L.M. Trends in the scientific literature on phytoplankton. Limnology, 2008, 9(2), 153-158. http://dx.doi. org/10.1007/s10201-008-0242-8.

CARNEIRO, F.M., NABOUT, J.C., VIEIRA, L.C.G., ROLAND, F. and BINI, L.M. Determinants of chlorophyll-a concentration in tropical reservoirs. Hydrobiologia, 2014, 740(1), 89-99. http://dx.doi. org/10.1007/s10750-014-1940-3.

CARPENTER, S.R. Eutrophication of aquatic ecosystems: Bistability and soil phosphorus. Proceedings of the National Academy of Sciences of the United States of America, 2005, 102(29), 10002-10005. http://dx.doi.org/10.1073/ pnas.0503959102. PMid:15972805.

CARPENTER, S.R., BOOTH, E.G., KUCHARIK, C.J. and LATHROP, R.C. Extreme daily loads: role in annual phosphorus input to a north temperate lake. Aquatic Sciences, 2015, 77(1), 71-79. http:// dx.doi.org/10.1007/s00027-014-0364-5.

CENTRAL INTELLIGENCE AGENCY - CIA. The world factbook [online]. Langley: CIA, 2017 [viewed 09 May 2016]. Available from: https://www.cia. gov/library/publications/the-world-factbook/geos/ bc.html

COTTINGHAM, K.L., CARPENTER, S.R. and AMAND, A.L.S. Responses of epilimnetic phytoplankton to experimental nutrient enrichment in three small seepage lakes. Journal of Plankton Research, 1998, 20(10), 1889-1914. http://dx.doi. org/10.1093/plankt/20.10.1889.

CSARDI, G. and NEPUSZ, T. The igraph software package for complex network research. Inter Journal Complex Systems, 2006, 1695, 1-9.
DONALD, D.B., BOGARD, M.J., FINLAY, K. and LEAVITT, P.R. Comparative effects of urea, ammonium, and nitrate on phytoplankton abundance, community composition, and toxicity in hypereutrophic freshwaters. Limnology and Oceanography, 2011, 56(6), 2161-2175. http:// dx.doi.org/10.4319/lo.2011.56.6.2161.

DOWNING, J.A., MCCLAIN, M., TWILLEY, R., MELACK, J.M., ELSER, J., RABALAIS, N.N., LEWIS, W.M. Jr., TURNER, R.E., CORREDOR, J., SOTO, D., YANEZ-ARANCIBIA, A., KOPASKA, J.A. and HOWARTH, R.W.The impact of accelerating land-use change on the N-Cycle of tropical aquatic ecosystems: Current conditions and projected changes. Biogeochemistry, 1999, 46(1-3), 109-148. http://dx.doi.org/10.1007/BF01007576.

DRUPP, P., CARLO, E.H., MACKENZIE, F.T., BIENFANG, P. and SABINE, C.L. Nutrient inputs, phytoplankton response, and $\mathrm{CO} 2$ variations in a semi-enclosed subtropical embayment, Kaneohe Bay, Hawaii. Aquatic Geochemistry, 2011, 17(4-5), 473498. http://dx.doi.org/10.1007/s10498-010-9115-y.

FIGUEREDO, C.C. and GIANI, A. Ecological interactions between Nile tilapia (Oreochromis niloticus, L.) and the phytoplanktonic community of the Furnas Reservoir (Brazil). Freshwater Biology (Print), 2005, 50(8), 1391-1403. http://dx.doi. org/10.1111/j.1365-2427.2005.01407.x.

FINLAY, S.C., NI, C. and SUGIMOTO, C.R. New methods for an old debate: utilizing reader response to investigate the relationship between collaboration and quality in academic journal articles. Library \& Information Science Research, 2012, 34(2), 131-137. http://dx.doi.org/10.1016/j.lisr.2011.11.003.

FONTANA, L., ALBUQUERQUE, A.L.S., BRENNER, M., BONOTTO, D.M., SABARIS, T.P.P., PIRES, M.A.F., COTRIM, M.E.B. and BICUDO, D.C. The eutrophication history of a tropical water supply reservoir in Brazil. Journal of Paleolimnology, 2014, 51(1), 29-43. http://dx.doi.org/10.1007/s10933013-9753-3.

HAKANSON, L. Factors and criteria to quantify coastal area sensitivity/vulnerability to eutrophication: Presentation of a sensitivity index based on morphometrical parameters. International Review of Hydrobiology, 2008, 93(3), 372-388. http://dx.doi. org/10.1002/iroh.200711033.

IGLIČ, H., DOREIAN, P., KRONEGGER, L. and FERLIGOJ, A. With whom do researchers collaborate and why? Scientometrics, 2017, 112(1), 153-174. http://dx.doi.org/10.1007/s11192-0172386-y. PMid:28725095.

JESPER, A.H. and LAAMANEN, M. Eutrophication in the Baltic Sea: an integrated thematic assessment of the effects of nutrient enrichment in the Baltic Sea region. Baltic Sea Environment Proceedings, 2009, 115B, 1-148. 
JOHNSON, P.T., CHASE, J.M., DOSCH, K.L., HARTSON, R.B., GROSS, J.A., LARSON, D.J., SUTHERLAND, D.R. and CARPENTER, S.R. Aquatic eutrophication promotes pathogenic infection in amphibians. Proceedings of the National Academy of Sciences of the United States of America, 2007, 104(40), 15781-15786. http://dx.doi. org/10.1073/pnas.0707763104. PMid:17893332.

JONES, J.I. and JEPPESEN, E. 2007. Body size and trophic cascades in lakes. In: A.G. HILDREW, D.G. RAFFAELLI and R. EDMONDS-BROWN. Body size: the structure and function of aquatic ecossystem. New York: Cambridge, 2007, pp. 118-139. http:// dx.doi.org/10.1017/CBO9780511611223.008.

KOKOCIŃSKI, M., AKÇAALAN, R., SALMASO, N., STOYNEVA-GÄRTNER, M.P. and SUKENIK, A. Expansion of alien and invasive cyanobacteria. In: J. MERILUOTO, L. SPOOF and G.A. CODD, eds. Handbook of cyanobacterial monitoring and cyanotoxin analysis. United Kigdom: John Wiley \& Sons, 2017, pp. 28-39. http://dx.doi. org/10.1002/9781119068761.ch4.

LAPOINTE, B.E. and BEDFORD, B.J. Drift rhodophyte blooms emerge in Lee County, Florida, USA: evidence of escalating coastal eutrophication. Harmful Algae, 2007, 6(3), 421-437. http://dx.doi. org/10.1016/j.hal.2006.12.005.

LEGENDRE, P. and LEGENDRE, L. Numerical ecology. 2nd ed. Amsterdam: Elsevier, 1998.

LEIMU, R. and KORICHEVA, J. Does scientific collaboration increase the impact of ecological articles? Bioscience, 2005, 55(5), 438-443. http:// dx.doi.org/10.1641/0006-3568(2005)055[0438:DS CITI]2.0.CO;2.

LIU, Y., CHEN, W., LI, D., HUANG, Z., SHEN, Y. and LIU, Y. Cyanobacteria-/cyanotoxincontaminations and eutrophication status before Wuxi Drinking Water Crisis in Lake Taihu, China. Journal of Environmental Sciences (China), 2010, 23(4), 575-581. http://dx.doi.org/10.1016/S10010742(10)60450-0. PMid:21793398.

MENEGHINI, R., MUGNAINI, R. and PACKER, A.L. International versus national oriented Brazilian scientific journals. A scientometric analysis based on SciELO and JCR-ISI databases. Scientometrics, 2006, 69(3), 529-538. http://dx.doi.org/10.1007/ s11192-006-0168-z.

MIGUEL, S., MOYA-ANEGÓN, F. and HERREROSOLANA, V. The impact of the socio-economic crisis of 2001 on the scientific system of Argentina from the scientometric perspective. Scientometrics, 2010, 85(2), 495-507. http://dx.doi.org/10.1007/ s11192-010-0266-9.

NABOUT, J.C., CARNEIRO, F.M., BORGES, P.P., MACHADO, K.B. and HUSZAR, V.L.M. Brazilian scientific production on phytoplankton studies: national determinants and international comparisons. Brazilian Journal of Biology $=$ Revista Brasileira de Biologia, 2015, 75(1), 216-223. http://dx.doi.org/10.1590/1519-6984.11713. PMid:25945640.

NABOUT, J.C., CARVALHO, P., PRADO, M.U., BORGES, P.P., MACHADO, K.B., HADDAD, K.B., MICHELAN, T.S., CUNHA, H.F. and SOARES, T.N. Trends and biases in global climate change literature. Natureza \& Conservação, 2012, 10(1), 45-51. http://dx.doi.org/10.4322/ natcon.2012.008.

OKSANEN, J.F., BLANCHET, G., KINDT, R., LEGENDRE, P., MINCHIN, P.R., O'HARA, R., SIMPSON, G.L., SOLYMOS, M.P., STEVENS, H.H. and WAGNER, H. Vegan: Community Ecology Package. R package version 3.1.1 [software]. Vienna: The R Foundation for Statistical Computing, 2013.

OLIVEIRA, D.E., FERRAGUT, C. and BICUDO, D.C. Relationships between environmental factors, periphyton biomass and nutrient content in Garças Reservoir, a hypereutrophic tropical reservoir in southeastern Brazil. Lakes and Reservoirs: Research and Management, 2010, 15(2), 129-137. http://dx.doi. org/10.1111/j.1440-1770.2010.00428.x.

PAERL, H.W., HALL, N.S. and CALANDRINO, E.S. Controlling harmful cyanobacterial blooms in a world experiencing anthropogenic and climatic induced change. The Science of the Total Environment, 2011, 409(10), 1739-1745. http://dx.doi.org/10.1016/j. scitotenv.2011.02.001. PMid:21345482.

POSCH, T., KÖSTER, O., SALCHER, M.M. and PERNTHALER, J. Harmful filamentous cyanobacteria favoured by reduced water turnover with lake warming. Nature Climate Change, 2012, 2(11), 809-813. http://dx.doi.org/10.1038/ nclimate1581.

QIN, B., ZHU, G., GAO, G., ZHANG, Y., LI, W., PAERL, H.W. and CARMICHAEL, W.W. A drinking water crisis in Lake Taihu, China: linkage to climatic variability and lake management. Environmental Management, 2010, 45(1), 105-112. http://dx.doi.org/10.1007/s00267-009-9393-6. PMid:19915899.

REYNOLDS, C.S., HUSZAR, V.L., NASELLIFLORES, L. and MELO, S. Towards a functional classification of the freshwater phytoplankton. Journal of Plankton Research, 2002, 24(5), 417-428. http://dx.doi.org/10.1093/plankt/24.5.417.

RONDA-PUPO, G.A. and KATZ, J.S. The power law relationship between citation impact and multiauthorship patterns in articles in Information Science \& Library Science journals. Scientometrics, 2016, 2016, 1-14.

SAETRE, M.M.L., DALE, B., ABDULLAH, M.I. and SAETRE, G.-P. Dinoflagellate cysts as potential indicators of industrial pollution in a Norwegian Fjord. Marine Environmental Research, 1997, 
44(2), 167-189. http://dx.doi.org/10.1016/S01411136(96)00109-2.

SANGIORGI, F. and DONDERS, T.H. Reconstructing 150 years of eutrophication in the north-western Adriatic Sea (Italy) using dinoflagellate cysts, pollen and spores. Estuarine, Coastal and Shelf Science, 2004, 60(1), 69-79. http://dx.doi.org/10.1016/j. ecss.2003.12.001.

SOARES, M.C.S., HUSZAR, V.L.M. and ROLAND, F. Phytoplankton dynamics in two tropical rivers with different degrees of human impact (southeast brazil). River Research and Applications, 2007, 23(7), 698-714. http://dx.doi.org/10.1002/rra.987.

SUIKKANEN, S., PULINA, S., ENGSTRÖMÖST, J., LEHTINIEMI, M., LEHTINEN, S. and BRUTEMARK, A. Climate change and eutrophication induced shifts in northern summer plankton communities. PLoS One, 2013, 8(6), e66475. http://dx.doi.org/10.1371/journal. pone.0066475. PMid:23776676.

THOMAZ, S.M., SOUZA, D.C. and BINI, L.M. Species richness and beta diversity of aquatic macrophytes in a large subtropical reservoir (Itaipu Reservoir, Brazil): the influence of limnology and morphometry. Hydrobiologia, 2003, 505(1), 119-128. http://dx.doi. org/10.1023/B:HYDR.0000007300.78143.e1.

TILMAN, D., FARGIONE, J., WOLFF, B., D’ANTONIO, C., DOBSON, A., HOWARTH, R., SCHINDLER, D., SCHLESINGER, W.H.,
SIMBERLOFF, D. and SWACKHAMER, D. Forecasting agriculturally driven global environmental change. Science, 2001, 292(5515), 281-284. http://dx.doi.org/10.1126/science. 1057544.

PMid:11303102.

TRIUNFOL, M.L. Latin American science moves into the spotlight. Cell, 2007, 131(7), 1213-1216. http://dx.doi.org/10.1016/j.cell.2007.12.008. PMid:18160028.

VILMI, A., KARJALAINEN, S.M., LANDEIRO, V.L. and HEINO, J. Freshwater diatoms as environmental indicators: evaluating the effects of eutrophication using species morphology and biological indices. Environmental Monitoring and Assessment, 2015, 187(5), 243. http://dx.doi.org/10.1007/s10661-0154485-7. PMid:25864081.

VÖRÖSMARTY, C.J., MCINTYRE, P.B., GESSNER, M.O., DUDGEON, D., PRUSEVICH, A., GREEN, P., GLIDDEN, S., BUNN, S.E., SULLIVAN, C.A., LIERMANN, C.R. and DAVIES, P.M. Global threats to human water security and river biodiversity. Nature, 2010 , 467(7315), 555-561. http://dx.doi.org/10.1038/ nature09440. PMid:20882010.

Received: 09 May 2016 Accepted: 15 January 2018 